PURBAWIDYA: Jurnal Penelitian dan Pengembangan Arkeologi p-ISSN: 2252-3758, e-ISSN: 2528-3618 Akreditasi LIPI No. 695/Akred/ P2MI-LIPI/07/2015 Vol. 6(2), November 2017, pp 117 - 130 DOI: doi.org/10.24164/pw.v6i2.205

\title{
INTERPRETASI BATU PABEASAN DI DESA CIBIRU WETAN KABUPATEN BANDUNG
}

\section{The Interpretation of Batu Pabeasan in Cibiru Wetan, Kabupaten Bandung}

\author{
Rusyanti \\ Balai Arkeologi Jawa Barat \\ Jln. Raya Cinunuk KM17 Cileunyi Bandung \\ E-mail: rusyanti08@gmail.com \\ Naskah diterima 20 Oktober 2017 - Revisi terakhir 17 November 2017 \\ Disetujui terbit 23 November 2017 - Tersedia secara online 30 November 2017
}

\begin{abstract}
There were many Archaeological artifacts found in Indonesia. The remains are from prehistoric, classic and Islam periods. One of the classic artifacts is lumpang alu stone presented in many forms and often presumed as lingga-yoni. This paper aims to interpret the function and the meaning of Batu Pabeasan in Desa Cibiru Wetan Kabupaten Bandung and its correlation to lingga-yoni. Through archaeological survey and iconographical analysis and historical approach it is found that Batu Pabeasan did not show the details seen as a religious artifact (ideofact) as lingga-yoni but more opt to economic tools (technofact) presented through its name. This may be related to people who experienced agricultural activities, within the meanings of hopes and fertility.
\end{abstract}

Keywords: lingga-yoni, lumpang batu, Bandung.

\begin{abstract}
Abstrak
Artefak arkeologi banyak ditemukan di Indonesia. Tinggalan tersebut berasal dari masa prasejarah, klasik, hingga Islam. Lumpang batu dengan berbagai variasinya merupakan salah satu artefak arkeologi. Banyak yang berpendapat bahwa lumpang batu bisa jadi sebagai lingga-yoni. Salah satu tinggalan lumpang batu adalah Batu Pabeasan di Desa Cibiru Wetan, Kabupaten Bandung. Penelitian ini bertujuan menganalisis fungsi dan makna Batu Pabeasan dan kaitannya dengan dugaan sebagai lingga-yoni. Dengan menggunakan metode survei dan analisis ikonografi dengan pendekatan sejarah diketahui bahwa Batu Pabeasan tidak memperlihatkan ciri artefak religi (idiofact) sebagai linggayoni, tetapi lebih memperlihatkan ciri alat yang berfungsi ekonomis (technofact) yang berhubungan dengan aktivitas pertanian. Lumpang batu erat kaitannya dengan aktivitas pertanian yang mempunyai makna pengharapan dan kesuburan.
\end{abstract}

Kata kunci: lingga-yoni, lumpang batu, Bandung

\section{PENDAHULUAN}

Artefak arkeologi banyak ditemukan di Indonesia. Tinggalan tersebut berasal dari masa prasejarah, klasik, dan Islam. Salah satu artefak arkeologi yang ditemukan adalah Batu Pabeasan. Juru kunci setempat, Rohman, menyatakan bahwa pabeasan berasal dari bahasa Sunda, yaitu 
$p a+$ beas (padi) + an yang berarti 'batu tempat menumbuk padi menjadi beras'.

Batu tempat menumbuk padi menjadi beras di Indonesia disebut dengan berbagai istilah, seperti watu lumpang (Jawa), batu lasuang (Sumatera), palungeng (Bugis), assung (Makassar), dan issong (Toraja). Di Sulawesi Selatan lumpang batu dikenal dengan istilah lokal, yaitu yang bentukbundar disebut atengngang dan bentuk persegi panjang disebut addonrang (Sukendar, 1980; Wiradnyana, 2011). Berbagai nama lokal tersebut menandakan bahwa lumpang batu dan sejenisnya merupakan hasil budaya materi yang bersifat etnografis dan di beberapa tempat masih dikenal.

Temuan lumpang batu dan sejenisnya banyak ditemukan pada situs-situs purbakala di Indonesia dan berasal dari rentang masa yang panjang sehingga berdampak pada interpretasi fungsi dan maknanya yang beranekaragam. A.C. Kruyt yang didukung sebagian besar sarjana sepakat mengatakan bahwa fungsi lumpang batu ialah sebagai penumbuk biji-bijian, sedangkan A.N.J.Th. à Th. van der Hoop menyatakan bahwa lumpang batu berhubungan erat dengan magis religius dan kematian (Sukendar, 1980). Pendapat lain mengenai lumpang batu dinyatakan oleh arkeolog, Wiradnyana, yang mengatakan bahwa lesung batu mempunyai banyak aspek yang berkaitan dengan kehidupan masyarakatnya. Lesung batu dapat berkait dengan aspek teknologi, lingkungan, ekonomi, religi, dan sosial. Menarik bahwa keberadaan lesung batu berkait dengan hamoraon (harta benda), yaitu suatu kekayaan bendawi yang dapat menimbulkan kesan yang berkaitan dengan status sosial (Wiradnyana, 2011). Pada intinya semua penarikan simpulan tersebut berkaitan dengan konteks temuannya.
Dalam konteks arkeologi, lumpang batu disebut juga dengan pipisan dan lumpang. Keduanya mempunyai fungsi yang sama, yaitu sebagai alat pelumat/ penggerus. Pipisan pada umumnya berdataran lumat, rata, dan berkaki. Pipisan mempunyai dua alat, yaitu grinding stone atau metate, bersifat pasif, dan berfungsi melumatkan bahan ramuan, sementara gandik atau mano yang bersifat aktif berfungsi sebagai alat penggerus atau pelumatnya. Berbeda dengan pipisan, lumpang atau mortar terdiri atas bidang yang berupa cekungan atau lubang berukuran $20-35 \mathrm{~cm}$ di bagian tengahnya. Pasangan lumpang adalah batu penumbuk yang disebut alu (Simanjuntak, 2008).

Di Jawa Barat temuan lumpang batu non-removeable atau tidak dapat dipindahkan di antaranya ditemukan di Situs Parigi, Lebak Banten (Sudarti, 2008); Pasir Lulumpang, Garut (Falah \& Yondri, 1995); Gunung Lumpang, Cirebon (Sudarti, 2001); Astana Gede, Kawali yang disebut pangeunteungan (Saptono, 2006); dan di Keraton Kasepuhan dan Kanoman Cirebon. Temuan lumpang batu di Garut dan Gunung Lumpang dikaitkan dengan aktivitas pada masa tradisi megalitik. Temuan lumpang batu pangenteungan di Situs Kawali dikaitkan dengan arti sebagai 'cermin' atau tempat bercermin, dan temuan di Cirebon berdasarkan konteksnya dikaitkan dengan fungsi dan makna simbolis berkait dengan metode Islamisasi (Rusyanti, 2011). Batu Pabeasan di Desa Cibiru Wetan merupakan temuan warga pada tahun 2012 dan belum diketahui fungsi dan maknanya.

Di Jawa Barat Batu Pabeasan atau lumpang batu merupakan temuan penting karena mengandung berbagai interpretasi 
yang berbeda-beda dan kontekstual. Oleh karena itu, permasalahan yang dibahas dalam tulisan ini adalah fungsi dan makna Batu Pabeasan di Desa Cibiru Wetan, Kecamatan Cileunyi, Kabupaten Bandung.

Tujuan khusus tulisan ini adalah mengetahui fungsi dan makna Batu Pabeasan di Desa Cibiru Wetan, Kabupaten Bandung secara kontekstual. Pemahaman tersebut penting dilakukan sebagai upaya memahami berbagai perilaku budaya yang ada pada masyarakat masa lampau berdasarkan tinggalan materinya, sebagai suatu identitas dan entitas yang tidak terpisahkan.

Metode yang digunakan dalam penelitian ini adalah metode kualitatif dengan menitikberatkan analisis menurut bidang arkeologi, yaitu analisis khusus dan analisis kontekstual. Analisis khusus merupakan analisis yang menitikberatkan pada ciri-ciri fisik artefak, sedangkan analisis kontekstual menitikberatkan pada hubungan antardata arkeologi. Kedua analisis ini dilakukan karena pada dasarnya semua benda arkeologi mempunyai tiga dimensi arkeologi, yaitu dimensi bentuk, ruang, dan waktu. Dimensi bentuk mengacu pada bentuk tiga dimensi serta ukuran benda arkeologi, dimensi ruang mengacu pada lokasi tempat benda tersebut ditemukan, dan dimensi waktu mengacu pada pertanggalannya (Simanjuntak, 2008).

\section{Analisis Khusus/Artefak}

Kegiatan analisis khusus merupakan tahap yang sangat penting dalam penelitian arkeologi sebab melalui analisis khusus atau disebut juga dengan analisis artefak akan dapat diketahui karakter yang dimiliki artefak sebagai suatu hasil karya dan hubungannya dengan artefak atau kasus lainnya sehingga dapat diketahui karakter budaya masyarakat pendukungnya.

Tahap analisis khusus/artefak terdiri atas

1. tahap identifikasi, yaitu tahap menentukan atribut-atribut yang dimiliki;

2. tahap perekaman, yaitu tahap memasukkan data dalam formulir atau struktur pangkalan data (data base);

3. tahap pengolahan, yaitu tahap mencari korelasi data antarartefak atau konteks lain.

Langkah kerja yang dilakukan dalam analisis khusus adalah mengamati artibut artefak yang dianalisis. Berdasarkan jenisnya, atribut dapat dibagi menjadi tiga kategori berikut:

1. atribut bentuk (formal attribute), yaitu atribut yang berkaitan dengan bentuk tiga dimensi, bagian-bagian, serta ukuran metrik artefak;

2. atribut teknologi (technological attribute), yaitu atribut yang berkaitan dengan bahan, teknik pembuatan, teknik penyelesaian, dan teknik hias artefak;

3. atribut gaya (stylistic attribute), yaitu atribut yang berkaitan dengan ragam hias, motif hias, dan pola hiasan artefak (Simanjuntak, 2008).

Hasil penelitian disajikan dengan mengikuti metode penelitian deskriptif, yaitu menguraikan data dan fenomena yang diamati yang mengandung pola-pola yang khas dan mengandung unsur studi kasus, perbandingan, hubungan/korelasi, dan pengembangnnya. Tujuanya adalah memberikan gambaran dan justifikasi berdasarkan fenomena dan kondisikondisi faktual yang meliputinya atau konteksnya. 


\section{PEMBAHASAN}

\section{Lumpang Batu di Jawa Barat}

Di Jawa Barat lumpang batu dalam bentuk fitur (non-removable artifact) berupa dua bongkah batu dengan bentuk dasar silinder dan kubus. Bentuk umum tersebut sering kali diduga sebagai lingga danyoniyang dikenal dalam kepurbakalaan masa klasik (Hindu-Buddha) sehingga perlu diteliti sejauh mana kaitan Batu Pabeasan dengan dugaan tersebut.

Penelusuran mengenai lingga-yoni akan berkait dengan penelitian-penelitian sebelumnya, yaitu pada masa prasejarah. Sukendar (1977) sebagaimana yang dikutip oleh (Saringendyanti, 1998) menyatakan bahwa akar asal usul linggayoni dapat dianggap sebagai kelanjutan konsep menhir pada tradisi megalitik. Menurut Sukendar, menhir atau batu tegak memiliki tiga fungsi, yaitu yang berkaitan dengan upacara keagamaan (religius/ sakral), penguburan, dan pembatas bangunan yang bersifat profan. Mengenai perbedaan fungsi tersebut Saringendyanti sepakat dengan Sukendar bahwa hal tersebut bergantung pada konteksnya (Saringendyanti, 1998).

Di Jawa Barat penelusuran batu tegak yang berasosiasi dengan lingga-yoni (religius/sakral) ditemukan pada Prasati Kawali II dan IV, berbahasa Sunda Kuna. Epigraf Titi Surti Nastiti menuliskan hasil penelitiannya pada Prasasti Kawali II dan IV berbunyi:

1. Say Hiyay Lingga Hiyay

2. Say Hiyay Liy bigba

yang berarti

1. Sang Hyang Ling- ga Hyang

2. Sang Hiyang Lingga Bingba (arca).
Tulisan tersebut terpahat pada batu tegak dengan bentuk sederhana, tanpa ciri ikonografis. Tulisan pada batu jelas menyebutkan batu tersebut sebagai lingga. Pada masa Islam fungsi menhir yang berkaitan dengan penguburan, kemudian diasosiasikan sebagai nisan. Nisannisan tersebut diantaranya terdapat pada makam Pangeran Usman dan Putri Baya Margasari di Situs Astana Gede Kawali; makam di Situs Pasir Meong, Kecamatan Cililin, Bandung Barat (Boedi,2004); makam di Pandeglang dan Cianjur (Sukendar, 1983); makam-makam di Desa Salakaria, Kecamatan Sukadana, Ciamis yang nisannya berupa batu tegak sebagai ciri pengaruh Pra-Islam (Latifundia, 2013).

Selain perubahan pada area sakral, menhir juga mengalami perubahan pada area profan. Salah satunya adalah sebagai penguat bangunan atau umpak yang tidak hanya ditemukan di Jawa Barat, tetapi juga di Jawa Timur, seperti di masjid kuno di Kabupaten Purworejo dan Nganjuk (Montana, 1996). Perubahan pada area profan inilah yang kemudian sering ditemukan pada objek lingga-yoni yang diindikasikan mengalami stilisasi atau penyamaran, baik dari segi bentuk maupun nama yang menjauhi kaidah ikonografi, seperti perubahan bentuk nama linggayoni di Keraton Cirebon yang disesuaikan dengan kondisi setempat.

Teknik stilir di Cirebon tersebut dapat dikatakan merupakan ide genius karena perubahan bentuk dan makna yang terjadi berkaitan dengan metode Islamisasi dengan pendekatan psikologis dan ekonomis. Pendekatan psikologis dilakukan dengan cara menempatkan objek yang semula berada di area sakral ke area profan, yaitu di sitinggil dan 
alun-alun yang lebih merupakan area semipublik dan publik. Sementara itu, pendekatan ekonomis dilakukan dengan cara mengganti fungsi lumpang alu, yang semula dikenal sebagai penumbuk padi atau erat kaitannya dengan aktivitas agraris, menjadi alat yang berkait dengan aktivitas pengolahan hasil laut/ekonomi bahari yang terkenal pada masa itu, yaitu terasi (Rusyanti, 2011). Dengan cara ini maka fungsi dan makna yang sebelumnya sakral berubah menjadi lebih profan dan dekat dengan ekonomi keseharian masyarakatnya.

\section{Situs Batu Pabeasan dan Sekitarnya}

Batu Pabeasan terletak di RT 02/ RW11, Desa Cibiru Wetan, Kecamatan Cileunyi, Kabupaten Bandung. Letak batu berada pada 300 meter di sebelah utara Jalan Raya Cinunuk. Batu berada di tengah permukiman penduduk, di pinggir gang pada lahan yang dikelilingi tembok dengan atap terbuka. Lahan dimiliki warga setempat yang bernama Iin (67 tahun). Di sebelah barat terdapat Ci Biru.

Keberadaan batu, menurut Iin, sudah ada sejak dahulu (insitu) dan dijaga oleh keluargaya. Artefak lain di sekitar situs tidak pernah ditemukan. Warga sekitar tidak mengetahui seluk beluk batu. Mereka hanya mengetahui bahwa Batu Pabeasan sering kali dikunjungi peziarah untuk tujuan tertentu.

Batu Pabeasan merupakan dua batu andesit yang terletak berdampingan. Batu pertama berbentuk silinder dengan bagian menonjol. Panjang batu $23 \mathrm{~cm}$, lebar 20 $\mathrm{cm}$, dan tinggi $42 \mathrm{~cm}$. Lebar tonjolan bagian atas $35 \mathrm{~cm}$. Permukaan batu kasar dan berlumut serta tidak ditemukan hiasan. Batu kedua berbentuk kubus yang memiliki panjang $40 \mathrm{~cm}$, lebar $44 \mathrm{~cm}$, dan tinggi $48 \mathrm{~cm}$. Permukaan batu kasar. Dasar batu membentuk tiga bagian, yaitu bagian dasar, bagian badan, dan bagian atas. Bagian dasar berbentuk persegi empat dan tidak terdapat hiasan. Hiasan berupa garis terlihat pada bagian badan dan di atas permukaan. Pada bagian sisi atas terdapat jejak patah.

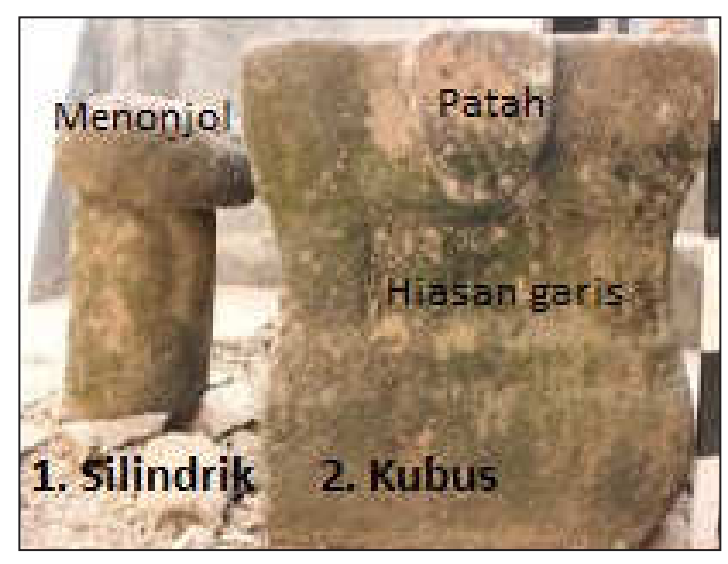

Gambar 1. Batu Pabeasan di Cibiru Wetan (Sumber: Dokumen Balai Arkeologi Bandung, 2012

Di sebelah utara $(150 \mathrm{~m})$ dari Batu Pabeasan terdapat makam Eyang Landros dan penjaganya. Di dekat makam terdapat cungkup untuk peziarah. Tidak banyak yang diketahui mengenai tokoh ini. Masyarakat mengenal Eyang Landros sebagai penyebar Islam di daerah tersebut. Tidak ditemukan artefak lain di sekitar makam. Kondisi makam utuh dan terawat, tetapi bentuk aslinya telah berubah. Pada 2000 jirat makam diganti dengan keramik berwarna pink, sedangkan nisannya masih berupa batu andesit. Pada bagian makam terdapat pohon hanjuang (Cordyline fruticosa). Di samping jirat terdapat batu bundar (insitu) dengan cekungan di tengahnya. 


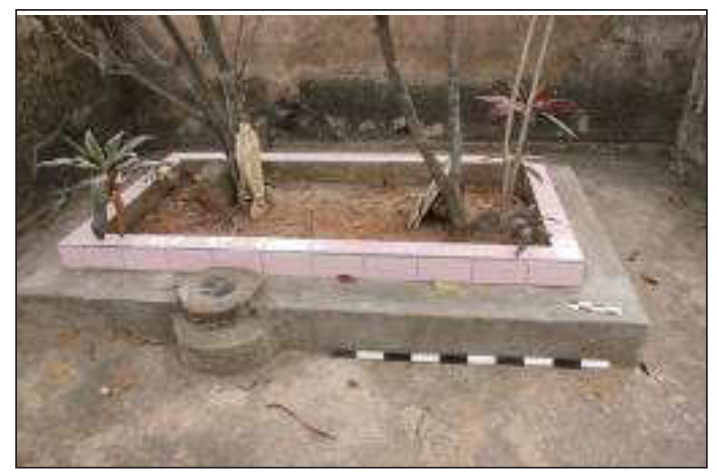

Gambar 2. Makam Eyang Landros (Sumber: Dokumen Balai Arkeologi Bandung, 2012)

\section{Fungsi Batu Pabeasan}

\section{Analisis Artefak}

Untuk mengetahui fungsi batu Pabeasan, terlebih dahulu dilakukan analisis artefak dengan mengurai atribut atau ciri-ciri artefak yang berdasarkan bentuk, teknologi, gaya, dan konteks yang mengacu pada Simanjuntak (2008).

Tabel 1. Analisis Artefak Batu Pabeasan

\begin{tabular}{|c|c|c|}
\hline \multirow{2}{*}{$\begin{array}{c}\text { Atribut } \\
\text { Artefak }\end{array}$} & \multicolumn{2}{|c|}{ Batu Pabeasan } \\
\hline & Batu Pertama & Batu Kedua \\
\hline Bentuk & 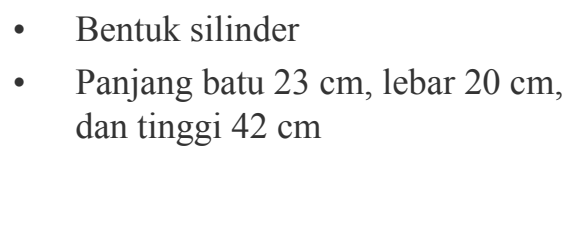 & 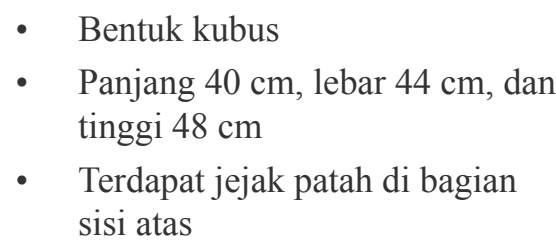 \\
\hline Teknologi & $\begin{array}{l}\text { - } \quad \begin{array}{l}\text { Bahan batu andesit yang berpori } \\
\text { (kasar) }\end{array} \\
\text { - Jejak pengerjaan kasar, dipahat }\end{array}$ & $\begin{array}{l}\text { - } \begin{array}{l}\text { Bahan batu andesit berpori } \\
\text { (kasar) }\end{array} \\
\text { - } \quad \text { Pengerjaan di pahat, jejak } \\
\text { pahatan membentuk garis sejajar }\end{array}$ \\
\hline Gaya & - Polos & - $\quad$ Profil berlipit (garis) sejajar \\
\hline Konteks & $\begin{array}{l}\text { - } \quad \text { Insitu, berada pada lokasi lahan ya } \\
\text { - } 200 \mathrm{~m} \text { di arah utara terdapat Sunga } \\
\text { - } \quad \text { I50 m di arah utara terdapat Makai } \\
\text { - } \quad \text { Tidak ditemukan artefak/temuan p } \\
\text { - } \quad \text { Dalam konteks skala kawasan berc } \\
\text { Bojongmenje di Rancaekek, Band }\end{array}$ & $\begin{array}{l}\text { lebih tinggi dari jalan raya } \\
\text { Cibiru } \\
\text { Kuno Eyang Landros } \\
\text { yerta } \\
\text { katan dengan lokasi Candi } \\
\text { g Timur. }\end{array}$ \\
\hline
\end{tabular}


Berdasarkan analisis pada Tabel 1, terdapat indikasi adanya jejak pengerjaan oleh manusia. Teknik pengerjaan batu terlihat kasar. Bentuk batu pertama terlihat sederhana dan menyerupai bentuk silinder, dan polos (tanpa hiasan), berbeda dengan batu kedua, yang memperlihatkan jejak hiasan berupa garis sejajar pada bagian bawah badan dan berulang di bagian atas badan sehingga memberi kesan minimalis dan proporsional. Jejak garis lainnya terdapat di atas permukaan batu, berbentuk garis tepi yang tidak terputus. Hal tersebut memperlihatkan adanya penekanan khusus pada bidang tersebut. Penekanan khusus tersebut bisa jadi berkaitan dengan fungsi benda, baik secara teknis maupun estetis.

Bagi para arkeolog lumpang batu sering kali mengandung dugaan sebagai lingga-yoni dan keberadaan bangunan suci. Oleh karena itu, analisis artefaktual yang digunakan, selain mengamati atribut bentuk, teknologi, dan gaya juga dilakukan analisis ikonografi. Ikonografi adalah ilmu yang berkaitan dengan identifikasi, deskripsi, klasifikasi dan interpretasi simbol, serta tema atau hal-hal yang berhubungan dengan pengarcaan atau visual art. Dalam konsep Hindu di India, lingga merupakan perwujudan Dewa Siwa dalam bentuk phallus atau penis yang menggambarkan sisi maskulinitas. Lingga biasanya bersanding dengan yoni atau vagina yang menggambarkan sisi feminim dari çakti atau pasangannya, yaitu Dewi Parvati. Lingga yang ditemukan di India pada kurun abad ke-1 SM hingga Abad ke-3 M digambarkan secara realistis, sedangkan setelahnya bentuk penggambaran lingga secara progresif mengalami perubahan dan cenderung lebih abstrak. Mitologi mengenai linggayoni berasal dari cerita epik dalam kitab kuno India, Purana. Dalam kitab tersebut diceritakan bahwa Siwa marah besar ketika Brahma dan Visnu mengutuk dirinya akibat perbutannya menggoda istri para pendeta di hutan Pegunungan Himalaya. Kemarahannya yang besar itu berdampak pada pembalasan Siwa dengan cara menjatuhkan his supreme phallus ke bumi dan memporakporandakan dunia. Lingga menjadi tenang ketika menyentuh yoni dari Dewi Uma/Parvati. Setelah penyatuan ini penciptaan dunia mulai terjadi dan seluruh dewa-dewa, termasuk Brahma dan Siwa mengakui kekuatan Siwa sebagai dewa tertinggi (Maulana, 2000).

Bagian-bagian lingga mempunyai penyebutansendiri,yaitubagian dasaryang berupa segiempat disebut brahmabhaga, bagian tengah yang berbentuk segidelapan disebut wisnubhaga, dan bagian puncak yang berbentuk bulat panjang disebut siwabhaga, sedangkan yoni secara konsep adalah landasan lingga yang menggambarkan kelamin wanita (vagina). Pada permukaan yoni terdapat lubang di bagian tengah untuk meletakkan lingga yang dihubungkan dengan cerat melalui sebuah saluran air sempit. Cerat hanya terdapat pada salah satu sisi dan berfungsi sebagai pancuran. Lingga dan yoni biasanya dihubungkan dengan kehadiran candi (Atmodjo, 1999). Manarudin Hadiyanto (1984) dalam (Istari, 2003) menyatakan bahwa bagian-bagian yoni secara lengkap adalah nala (cerat), jagati (ruang), padma (alas), kantha (leher), dan lubang untuk berdirinya lingga atau arca. 
Tabel 2. Bagian Lingga

\begin{tabular}{|c|c|c|c|}
\hline Lingga & \multicolumn{2}{|c|}{ Gambar } & Foto \\
\hline $\begin{array}{l}\text { Silinder/ } \\
\text { Siwabhaga }\end{array}$ & & & \\
\hline $\begin{array}{l}\text { Segi Delapan/ } \\
\text { Wisnubhaga }\end{array}$ & & Silva & \\
\hline $\begin{array}{l}\text { Segi Empat/ } \\
\text { Brahmabhaga }\end{array}$ & & Vishnu & \\
\hline $\begin{array}{l}\text { Bagian-Bagian } \\
\text { Lingga (Sumber: } \\
\text { Atmodjo, 1999) }\end{array}$ & $\begin{array}{l}\text { Gambar Irisan Lingga } \\
\text { (Sumber:http://www. } \\
\text { shivavishnutemple.ors } \\
\text { shivalinga.htm. Diaks } \\
\text { November 2017) }\end{array}$ & $\begin{array}{l}\text { nplhal/ } \\
\text { Senin, } 13\end{array}$ & $\begin{array}{l}\text { Lingga Jambansari, Ciamis } \\
\text { (Sumber: Widyastuti: 2005b) }\end{array}$ \\
\hline
\end{tabular}

Tabel 3. Bagian Yoni

\begin{tabular}{l} 
Yoni \\
\hline Padma/Alas
\end{tabular}

Dalam konteks arkeologi, keberadaan lingga-yoni sering kali dihubungkan dengan bangunan candi. Sri Utami Ferdinandus menambahkan bahwa yoni merupakan bagian dari bangunan suci dan ditempatkan di bagian tengah ruangan suatu bangunan suci. Yoni biasanya dipergunakan sebagai dasar arca atau lingga. Yoni juga dapat ditempatkan pada ruangan induk candi, seperti Candi 
Jawi di Jawa Timur. Berdasarkan konsep pemikiran Hindu, yoni adalah indikator arah letak candi (Ferdinandus, 1990 dalam Saringendyanti, 1998). Hubungan keberadaan lingga-yoni dengan candi juga dibuktikan dalam penelitian yang dilakukan BalaiArkeologi Jawa Barat pada 2012, dan 2013. Kajian terhadap bentuk lingga-yoni, kawasan geomorfologi, dan kawasan budaya mengindikasikan bahwa Situs Indihiang tempat lokasi lingga-yoni berada merupakan bangunan suci pada masa Hindu-Buddha (Widyastuti, 2012). Pembuktian tersebut semakin menguat pada penelitian tahun 2013. Singkapan struktur fondasi, indikasi tangga, dan temuan batu bulat di sekeliling linggayoni mengindikasikan adanya bangunan suci yang berupa batur tunggal dengan atap dari bahan yang mudah rusak (Widyastuti, 2017).

Berkait hubungan lingga-yoni dengan candi dapat pula berarti bahwa fungsi yoni, selain sebagai objek pemujaan, dapat juga sebagai dasar (tempat berdirinya) arca atau dengan kata lain sebagai lapik arca. Sementara itu, kaitan yoni sebagai indikator letak ruang utama candi, hal tersebut didasarkan pada aturan peletakan arca atau tokoh Hindu yang diatur dalam kitab Silpasastra. Letak lingga-yoni dalam candi Hindu biasanya berada di tengah yang tegak lurus dengan pintu masuk (biasanya di sebelah barat atau timur) dengan kehadiran arca Ganesa di belakangnya, Agastya di selatan, dan Durga di sebelah utara.

Di Jawa Barat lingga dan yoni yang ditemukan bentuknya beragam. Oleh karena itu, selain analisis artefak dan ikonografi, analisis konteks juga sangat penting. Hal tersebut sejalan dengan pendapat Wardha yang menyatakan bahwa lingga-yoni sebagai ayasa atau simbol Tuhan dalam berbagai bentuk manifestasinya dalam konteks arkeologi, sering kali berfungsi religius, seni, teknis, atau penggabungan ketiganya yang sukar dipisahkan dan dalam kenyataanya kita masih melihatnya bersama-sama (Wardha, 1985).

Berdasarkan uraian tersebut, analisis ikonografi Batu Pabeasan yang ditemukan di Desa Cibiru Wetan, Kecamatan Cileunyi, Kabupaten Bandung perlu dilakukan dengan cara mengurai atribut ikonografi dalam konsep lingga-yoni menurut pandangan beberapa ahli dengan realitas yang ada. Hasil analisis ikonografi tersebut terlihat dalam Tabel 4.

Berdasarkan uraian pada Tabel 4, temuan Batu Pabeasan di Desa Cibiru Wetan, meskipun secara bentuk umum memiliki kemiripan, tidak memperlihatkan detail ciri khusus yang bersifat ikonografis. Bentuk batu pertama atau jika diasumsikan sebagai lingga terlihat sangat sederhana dan tidak dijumpai yang disebut dengan Brahmabhhaga, Wisnubhaga, maupun Siwabhaga. Bentuk lingga yang tidak memiliki kaidah tiga tersebut juga dijumpai di Kawali, Ciamis dan Cirebon. Perihal kekhasan bentuk pada tinggalan arkeologi di Ciamis, bisa jadi berkaitan dengan perkembangan religi yang bercampur dengan kepercayaan asli (lokal) ataupun dengan keyakinan baru (Islam) (Widyastuti, 2005a). Dengan kata lain adanya pengaruh tersebut berdampak pada aspek bentuk yang tidak lagi sama persis dengan aturan Hindu (Gambar 3). 
Tabel 4. Analisis Ikonografi: Perbandingan Konsep Lingga-Yoni dan Atribut pada Batu Pabeasan

\begin{tabular}{|c|c|c|c|c|}
\hline \multicolumn{2}{|c|}{ Lingga-Yoni } & \multicolumn{2}{|c|}{ Batu Pabeasan } & \multirow[t]{2}{*}{ Keterangan } \\
\hline $\begin{array}{l}\text { Lingga } \\
\text { (Atmodjo, 1999:23) }\end{array}$ & $\begin{array}{l}\text { Yoni } \\
\text { (Hadiyanto dalam } \\
\text { Istari, 2003) }\end{array}$ & $\begin{array}{l}\text { Batu } \\
\text { Pertama } \\
\text { (silindrik) }\end{array}$ & $\begin{array}{l}\text { Batu Kedua } \\
\text { (kubus) }\end{array}$ & \\
\hline $\begin{array}{l}\text { Bagian dasar } \\
\text { berbentuk } \\
\text { segi empat } \\
\text { (brahmabhaga) }\end{array}$ & $\begin{array}{l}\text { Nala (cerat) } \\
\text { Terdapat lubang di } \\
\text { bagian tengah }\end{array}$ & $\begin{array}{l}\text { Bagian } \\
\text { dasar } \\
\text { silinder }\end{array}$ & $\begin{array}{l}\text { Patah; cerat? } \\
\text { (jejak lubang/ } \\
\text { saluran air } \\
\text { tidak ada) }\end{array}$ & \\
\hline $\begin{array}{l}\text { Bagian tengah } \\
\text { berbentuk segi } \\
\text { delapan } \\
\text { (vishnubhaga) }\end{array}$ & $\begin{array}{l}\text { Padma } \\
\text { (alas) }\end{array}$ & $\begin{array}{l}\text { Bagian } \\
\text { tengah } \\
\text { berbentuk } \\
\text { silinder }\end{array}$ & Tidak ada & \\
\hline \multirow[t]{3}{*}{$\begin{array}{l}\text { Bagian puncak } \\
\text { berbentuk bulat } \\
\text { panjang } \\
(\text { siwabhaga) }\end{array}$} & $\begin{array}{l}\text { Kantha } \\
\text { (leher) }\end{array}$ & $\begin{array}{l}\text { Bagian } \\
\text { puncak } \\
\text { berupa } \\
\text { tonjolan } \\
\text { asimetris }\end{array}$ & Samar & $\begin{array}{l}\text { Pada batu kedua } \\
\text { terdapat hiasan } \\
\text { lipit (garis) yang } \\
\text { sejajar dengan } \\
\text { bagian badan; lipit } \\
\text { berganda sering } \\
\text { dijumpai pada } \\
\text { bentuk yoni }\end{array}$ \\
\hline & $\begin{array}{l}\text { Jagati } \\
\text { (ruang) }\end{array}$ & & & \\
\hline & Lubang lingga & & $\begin{array}{l}\text { Tidak ada } \\
\text { Lubang lingga }\end{array}$ & \\
\hline
\end{tabular}
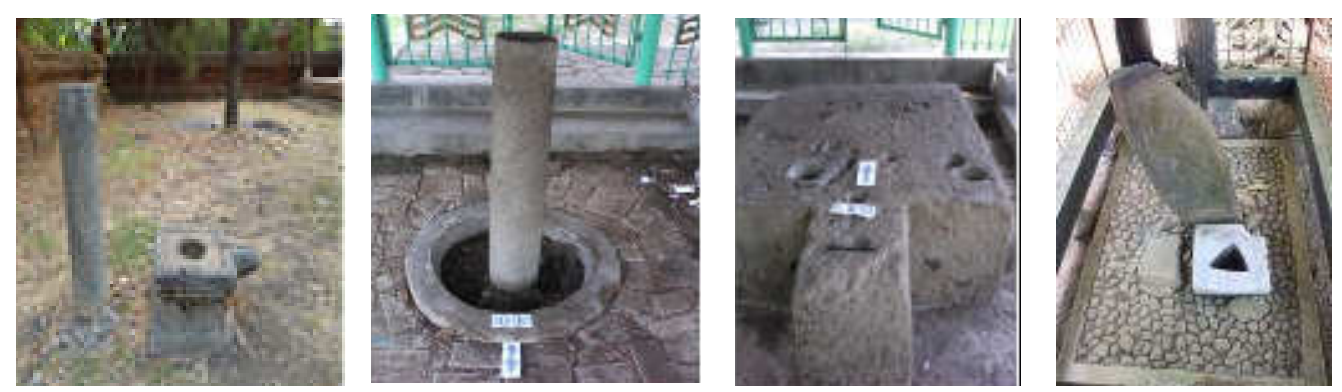

Gambar 3. Lingga-Yoni yang tidak berciri ikonografis Hindu-Buddha; Keraton Kasepuhan (a) dan Keraton Kanoman Cirebon (b, c) (Sumber: Rusyanti, 2011:70) dan Lingga-Yoni di Astana Gede Kawali (d) (Sumber: Dokumen Balai Arkeologi Bandung, 2011)

Hal serupa juga ditemui pada bentuk yoni Batu Pabeasan yang tidak memperlihatkan kaidah ikonografi Hindu. Pada yoni terdapat tonjolan batu yang patah dan menyerupai tonjolan cerat (nala), tetapi tidak ditemukan saluran air, begitu pula pada bagian tengahnya yang rata dan tidak dijumpai lubang (jagatil 
ruang) untuk tempat lingga. Hal tersebut memunculkan asumsi fungsi yoni yang lain, yaitu sebagai lapik atau dasar arca. Jika yang dimaksud arca tersebut adalah lingga yang ada sekarang, hal itu diragukan karena permukaan dasar lingga tidak rata sehingga tidak dapat berdiri tegak pada permukaan lapik yang datar. Oleh karena itu, sangat logis jika pada akhirnya lingga tersebut diletakkan di bagian samping yoni dengan dasar menyentuh tanah. Namun, jika pun benar yoni tersebut adalah lapik arca, arca yang berada di atasnya bukanlah lingga yang ada sekarang, tetapi arca lain yang sudah hilang. Sebagai contoh, berikut posisi lingga yang tepat diletakkan pada yoni di Situs Indihiang, Tasikmalaya (Gambar 4).

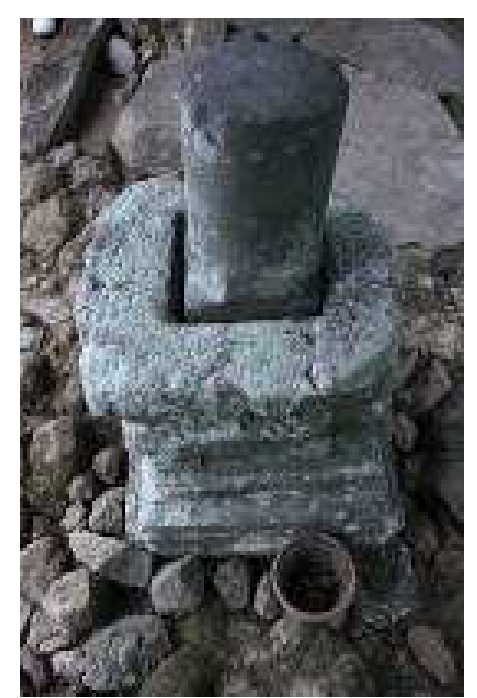

Gambar 4. Lingga-Yoni Indihiang, Tasikmalaya (Sumber: Dokumen Balai Arkeologi Jawa Barat, 2005)

Asumsi lain yang menguat berkait dengan fungsi yoni Batu Pabeasan terlihat dari adanya jejak garis tepi yang tidak terputus di atas permukaan batu. Walter Kaundern (1938) sebagaimana yang dikutip oleh (Sukendar, 1980) mendeskripsikan lumpang batu di
Sulawesi Tengah yang memiliki lubang dan permukaan yang halus yang memberi kesan telah dipakai. Bukti pemakaian diperkuat dengan adanya tonjolantonjolan pada pinggir lumpang batu yang berfungsi sebagai penahan biji-bijian agar tidak tumpah (Sukendar, 1980).

Yoni Batu Pabeasan tidak berlubang, tetapi memiliki permukaan batu yang halus dan tonjolan (garis tepi) yang memberi kesan berfungsi sebagai penahan biji-bijian. Indikasi tersebut sesuai dengan fungsi yoni sebagai benda teknis, sebagaimana fungsi lumpang atau mortar, yaitu sebagai alat penumbuk bijibijian. Lumpang berpasangan dengan alu. Apakah alu tersebut adalah lingga yang ada sekarang? Jika lingga berfungsi sebagai alu atau penggerus atau gandik, tidak ditemukan jejak pemakaian yang berupa sisi halus. Keseluruhan tekstur batu kasar dan bentuknya tidak ergonomis (nyaman) digunakan sebagai penggerus serta berat. Hal ini memunculkan asumsi fungsi lingga yang berbeda dengan yoni. Lingga Batu Pabeasan lebih mencirikan sebagai benda simbolis, bukan benda teknis. Hal tersebut sejalan dengan kecenderungan ciri adanya stilasi atau penyamaran bentuk yang sering ditemui pada objek lingga-yoni.

\section{Analisis Kontekstual}

Sejalan dengan asumsi Ferdinandus dalam Saringendyanti (1998) dan Atmodjo (1999) yang menyatakan bahwa keberadaan lumpang-batu atau sejenisnya sering kali berkaitan dengan tempat-tempat suci dan religius (candi), hal-hal yang perlu diperhatikan adalah lingkungan sekitar keberadaan temuan atau konteksnya. Objek-objek arkeologisreligius di Indonesia sering kali berada pada tempat yang tinggi dan berdekatan 
dengan sumber air. Dua indikator tersebut berkaitan dengan asumsi bahwa tempat sakral biasanya lebih tinggi dari dataran di sekitarnya dengan ketersediaan air sebagai sumber kehidupan.

Lokasi temuan Batu Pabeasan terletak di dataran yang tinggi dan dekat dengan sumber air, yaitu Ci Biru Wetan. Namun, ketiadaan data penyerta lain pada saat ini belum menguatkan indikasi adanya hubungan dengan keberadaan bangunan suci.

Keberadaan makam Eyang Landros sekitar $150 \mathrm{~m}$ di arah utara lingga beserta temuan batu bundar insitu di samping makam menimbulkan asumsi dalam konteks bahan batu yang sama dengan bahan Batu Pabeasan, yaitu dari batu andesit. Adapun dari mana sumber bahannya, saat ini belum diketahui. Hubungan antara keberadaan Makam EyangLandrosdan penyebutan batudengan istilah Batu Pabeasan memunculkan asumsi fungsi situs berlangsung pada masa Kepurbakalaan Islam di Jawa Barat.

Kepurbakalaan masa Islam di Jawa Barat berkaitan dengan penyebaran agama Islam yang gencar dari Cirebon dan Banten ke wilayah-wilayah di sekitarnya pada abad ke-16 M hingga jauh setelahnya. Kehadiran Makam Eyang Landros, berdasarkan ciri-ciri kepurbakalaan yang ada, tampaknya berasal dari masa yang jauh lebih muda jika dibandingkan dengan keberadaan Batu Pabeasan.

Eyang Landros merupakan tokoh lokal yang terkenal di daerah tersebut. Keberadaan makam tokoh-tokoh lokal penyebar Islam di Jawa Barat jumlahnya sangat banyak dan umumnya berasal dari kisaran akhir abad ke-18 hingga $21 \mathrm{M}$.

\section{Makna Batu Pabeasan}

Berdasarkan uraian, diketahui bahwa Batu Pabeasan atau bentuk formalnya berupa batu tegak, berdasarkan penelusuran tipologinya berpangkal pada bentuk tertua berupa menhir pada masa prasejarah dan berkaitan dengan fungsi religius dan sakral. Seiring dengan perkembangan zaman, menhir kemudian mengalami perubahan fungsi. Di wilayah lain bentuk tersebut mengalami perubahan lagi, sesuai dengan konteks zaman dan kebudayaan masyarakatnya. Pada masa klasik, batu tegak difungsikan sebagai media tulisan atau prasasti, sedangkan pada masa Islam, batu tegak berasosiasi dengan nisan. Pada masamasa berikutnya fungsi dan makna tersebut memiliki potensi pemaknaan kembali sesuai dengan konteksnya.

Beberapa poin yang muncul dari pemaknaan lumpang batu yang bermacam-macam tersebut ialah ada satu benang merah yang tidak berubah, yaitu representasi simbolis yang berakar pada aspek kepercayaan. Menhir, prasasti, dan nisan adalah benang merah yang selalu berkait dengan aspek religi dan religiusitas. Dari unsur namanya, Batu Pabeasan mengingatkan pada Dewi Sri, Dewi Padi, yang dikenal masyarakat Jawa. Masyarakat Sunda di Jawa Barat mengenalnya dengan Nyi Pohaci Sanghyang Asri. Mitologi mengenai Nyi Pohaci Sanghyang Asri muncul pada naskah Sunda Kuno Wawacan Sulanjana. Teks Wawacan Sulanjana adalah teks kuno yang sering dibacakan pada saat ritual padi. Wawacan mulai muncul sebagai khazanah kesusatraan Sunda pada abad ke-17 M. Pwah Aci (Pohaci) berarti 'mantra padi' Dewi Padi merupakan mite yang tergolong sangat tua. Johannes Jacobus Ras (1968) 
menduga Pwah Aci atau Sri-Sedana dalam Wawacan Sulanjana adalah nenek moyang leluhur orang Jawa, Pra-Hindu. Dewi Sri sering kali dianggap sebagai dewi yang menumbuhsuburkan kehidupan manusia dan sebagai regenerasi dari umat manusia (Kalsum, 2010).

Berdasarkan hal tersebut, perihal makna Batu Pabeasan dapat dimaknai sebagai benda teknis yang berkaitan dengan ekonomi agraris. Adanya dua unsur yang bersamaan, yaitu religi dan ekonomi pada objek arkeologi nyatanya memang tidak dapat dipisahkan, khususnya pada masyarakat agraris dan sederhana sebagai simbol dari pengharapan dan kesuburan (Koentjaraningrat, 1990; Taniardi, 2010). Jika ditelisik kembali, pemaknaan tersebut sama dengan makna lingga-yoni dalam mitologi Hindu, yaitu berkaitan dengan kesuburan dan penciptaan (regenerasi umat manusia) meskipun secara bentuk tidak sama persis dengan kaidah ikonografi Hindu.

\section{SIMPULAN}

Berdasarkan uraian sebelumnya dapat disimpulkan tiga poin penting sebagai berikut.

(1) Batu Pabeasan di Cibiru Wetan tidak memperlihatkan ciri ikonografis yang berkaitan dengan fungsi religius (idiofact) sebagai lingga-yoni, tetapi lebih menampakkan fungsi profane sebagai alat (technofact).

(2) Meskipun demikian, makna Batu Pabeasan dalam konteks sebagai teknofak mempunyai kaitan dengan budaya masyarakat agrikultur atau pertanian (ekonomi) yang tetap berakar pada nuansa keagamaan (religi), yaitu pengharapaan, kesuburan, dan penciptaan.

(3) Kronologi Batu Pabeasan tidak memperlihatkan ciri kekunoan ikonografis ataupun kontekstual sejarah sehingga dalam hal ini dianggap sebagai artefak yang bersifat etnografis.

\section{DAFTAR PUSTAKA}

Atmodjo, Y. S. (1999). Vademekum Benda Cagar Budaya. Jakarta: Direktorat Jenderal Kebudayaan, Direktorat Perlindungan dan Pembinaan Sejarah Purbakala.

Boedi, O. B. (2004). Fungsi Menhir Pada Masa Islam di Jawa Bagian Barat. In Agus Aris Munandar (Ed.), Teknologi dan Religi dalam Perspektif Arkeologi (pp. 55--63). Bandung: Ikatan Ahli Arkeologi Indonesia.

Falah, A. W., \& Yondri, L. (1995). Tinjauan Tentang Peninggalan Tradisi Megalitik di Situs Pasir Lulumpang, Cimareme, Kabupaten Garut. Jurnal Balai Arkeologi Bandung, (No.1), 87--97.

Istari, T. M. R. (2003). Arti Simbolis Pahatan Naga di Bawah Cerat Yoni di Singasari. Berkala Arkeologi Tahun XIII, (No.1), 53--62.

Kalsum. (2010). Kearifan Lokal dalam Wawacan Sulanjana: Tradisi Menghormati Padi pada Masyarakat Jawa Barat di Indonesia. Jurnal Sosiohumanika, 3(1), 79--94.

Retrieved from http://www.mindamasjournals.com/index.php/sosiohumanika/article/view/405

Koentjaraningrat. (1990). Pengantar Ilmu Antropologi. Jakarta: Rineka Cipta.

Latifundia, E. (2013). Pengaruh Budaya Pra-Islam pada Makam di Desa Salakaria, Kecamatan Sukadana, Ciamis. Purbawidya Jurnal Penelitian Dan Pengembangan Arkeologi, 2(1), 12--24. 
Maulana, R. (2000). Ikonografi Hindu. Depok: Fakultas Sastra Universitas Indonesia. Montana, S. (1996). Perbedaan dalam Cara Penyebaran Agama Islam di Jawa pada Abad ke-15--17 (Kajian Historiografi Lokal dan Asimilasi Tinggalan Arkeologi). Forum Arkeologi, 2.

Nastiti, T. S. (1996). Prasasti Kawali. Jurnal Penelitian Balai Arkeologi Bandung, (4), 19-37.

Rusyanti. (2011). Lingga Yoni di Kompleks Keraton Cirebon. In A. Akbar (Ed.), Arkeologi: Peran dan Manfaat Bagi Kemanusiaan (pp. 167--177). Bandung: Balai Arkeologi Bandung.

Saptono, N. (2006). Situs Astana Gede Kawali dalam Konteks Perubahan Budaya. In Dimensi Arkeologi Kawasan Ciamis (pp. 81--93). Bandung: Ikatan Ahli Arkeologi Indonesia Komda Jabar-Banten.

Saringendyanti, E. (1998). Menhir Bentuk Phallus di Jawa Barat sebagai Wujud dan Fungsi dari Dinamika Budaya Nusantara. In T. Djubiantono (Ed.), Dinamika Budaya Asia Tenggara-Pasifik Dalam Perjalanan Sejarah (pp. 113--118). Jakarta: Ikatan Ahli Arkeologi Indonesia Komda Jabar-Banten.

Simanjuntak, T. (Ed.). (2008). Metode Penelitian Arkeologi. Jakarta: Pusat Penelitian dan Pengembangan Arkeologi Nasional, Badan Pengembangan Sumberdaya Kebudayaan dan Pariwisata, Departemen Kebudayaan dan Pariwisata.

Sudarti. (2001). Sumberdaya Alam Situs Gunung Lumpang, Kabupaten Cirebon sebagai Pendukung Budaya Megalitik. In Manusia dan Lingkungan: Keberagaman Budaya dalam Kajian Arkeologi (pp. 13--25). Bandung: Ikatan Ahli Arkeologi Indonesia Komda Jabar-Banten.

Sudarti. (2008). Lingkungan dan Topografi Lahan Kaitannya dengan Penempatan Situssitus Arkeologi Masa Tradisi Megalitik dan Islam Kawasan Cibeber. In Arkeologi Penelitian dan Pemanfaatan Sumberdaya Budaya (pp. 73--88). Jakarta: Ikatan Ahli Arkeologi Indonesia Komda Jabar-Banten.

Sukendar, H. (1980). Tinjauan Tentang Tinggalan Megalitik di Daerah Sulawesi Tengah. In Pertemuan Ilmiah Arkeologi III (pp. 61--82). Jakarta: Proyek Penelitian dan Peninggalan Purbakala, Departemen Pendidikan dan Kebudayaan.

Sukendar, H. (1983). Peranan Menhir dalam Masyarakat Prasejarah di Indonesia. In Makalah dalam Pertemuan Ilmiah Arkeologi ke III (pp. 92--108). Jakarta: Departemen Pendidikan dan Kebudayaan.

Taniardi, P. N. (2010). Mengurai Makna di Balik Lingga dan Yoni. Kebudayaan, 5(1), 50-57.

Wardha I Wayan. (1985). Lingga (Suatu Kajian Simbol) (II). Jakarta.

Widyastuti, E. (n.d.-a). Laporan Hasil Penelitian Arkeologi Ikonografi Masa Hindu Budha di Kabupaten Ciamis dan Tasikmalaya, Jawa Barat. Bandung.

Widyastuti, E. (n.d.-b). Variasi Bentuk Lingga Yoni dalam Kaitannya dengan Perkembangan Religi. In S. Rahardjo (Ed.), Religi dalam Dinamika Masyarakat (pp. 60--71). Bandung: Ikatan Ahli Arkeologi Indonesia Komda Jabar-Banten.

Widyastuti, E. (2012). Bangunan Suci di Situs Indihiang, Tasikmalaya, Jawa Barat. In Heriyanti Untoro (Ed.), Arkeologi Ruang: Lintas Waktu Sejak Prasejarah Hingga Kolonial di Situs-situs Jawa Barat dan Lampung (pp. 31--42). Bandung: Alqa: Print.

Widyastuti, E. (2017). Arsitektur Bangunan Suci di Situs Indihiang Kota Tasikmalaya. Purbawidya Jurnal Pengembangan Dan Penelitian Arkeologi, 6(1), 19--31.

Wiradnyana, K. (2011). Lesung Batu Cerminan Pandangan Hidup Masyarakat Batak Toba. Berkala Arkeologi Sangkhakala, XIV(2), 266--286.

http://www.shivavishnutemple.org/templhal/shivalinga.htm 